\title{
Anxiolytic Activity of Intraventricularly Administered Atrial Natriuretic Peptide in the Rat
}

Salil K. Bhattacharya, M.D., Ph.D., Amit Chakrabarti, M.D., Merton Sandler, F.R.C., and Vivette Glover, D.Sc.

Rat atrial natriuretic peptide (ANP) was investigated for putative anxiolytic activity in rats, following intracerebroventricular (ICV) administration. ANP in doses of 200 and $500 \mathrm{ng} / \mathrm{rat}$ induced significant anxiolysis, comparable with that of lorazepam $(0.5 \mathrm{mg} / \mathrm{kg}, I P)$ in a variety of anxiety models (open-field, elevated plus-maze, social interaction, and novelty-induced feeding suppression tests). Isatin, an endogenous anxiogenic indole, shown to be an antagonist of $A N P$ in vitro, significantly inhibited the anxiolytic effect of ANP in the elevated plus-maze test in subanxiogenic doses. The anxiolytic action of ANP was unaffected by flumazenil, a benzodiazepine receptor antagonist. Conversely, the anxiolytic action of lorazepam was antagonized by flumazenil but not by isatin. The data indicate that ANP may function as an endogenous anxiomodulator, which may act in conjunction with isatin independently of benzodiazepine receptors. These results strengthen the evidence for links between physiological systems involved in anxiety and those in natriuresis.

[Neuropsychopharmocology 15:199-206, 1996]
KEY WORDS: Atrial natriuretic peptide; Anxiety; Lorazepam; Flumazenil; Isatin

Atrial natriuretic peptide (ANP), comprising 28 amino acid residues, was first isolated from rat atria (de Bold et al. 1981) and later identified in several mammalian tissues, including brain (Kawata et al. 1985; Morii et al. 1985). Subsequently, specific ANP receptors were delineated in the central nervous system (CNS) (AnandSrivastava and Trachte 1993). More recently, two related peptides, brain natriuretic peptide (BNP) and C-type

From the Department of Pharmacology (SKB, AC), Institute of Medical Sciences, Banaras Hindu University, Varanasi, India, the Departments of Chemical Pathology (MS) and of Pediatrics (VG), Queen Charlotte's and Chelsea Hospital, Goldhawk Road, London W6 OXG.

Address correspondence to: Professor S. K. Bhattacharya, Department of Pharmacology, Institute of Medical Sciences, Banaras Hindu University, Varanasi 221005, India.

Received July 18, 1995; revised September 14, 1995; accepted September 26, 1995 . natriuretic peptide (CNP), have been isolated from porcine brain and other tissues (Lang et al. 1992). However, doubts have been expressed whether BNP is present in rat brain (Bidzseranova et al. 1993). ANP and BNP share substantial amino acid sequence homology and have similar potency in their natriuretic, diuretic, vasorelaxant, and behavioral effects (Bidzseranova et al. 1992; Lang et al. 1992). Comparative studies have indicated that the cardiovascular, renal, and behavioral effects of ANP and BNP are indistinguishable from each other (Bidzseranova et al. 1992; Wigle et al. 1992). Both act as regulators of body fluid and blood pressure homeostasis in the CNS, as well as natriuretic hormones in the periphery (Nicholls 1994).

ANP has been investigated by Bidzseranova and her co-workers for its effects on learning and memory (reviewed by Bidzseranova et al. 1993), after intracerebroventricular (ICV) administration in rats. ANP and BNP had similar actions on cognitive functions in rats (Bidzseranova et al. 1992). Few attempts have been made 
to investigate other behavioral effects of ANP (AnandSrivastava and Trachte 1993). However, ANP has been reported to attenuate fear-motivated learning deficits in rats (Bidzseranova et al. 1992). ANP is known to influence central neurotransmitter activity, including the dopaminergic and cholinergic systems (Bidzseranova et al. 1993).

Isatin is an indole (2,3-dioxoindole) that appears to be endogenously generated in the brain and heart (Sandler et al. 1991) and is widely distributed in mammalian tissues and biological fluids, including the CNS (Glover et al. 1988; Glover and Sandler 1993). Isatin was shown to be a selective and potent ligand for brain ANP receptors and to competitively inhibit ANP-activated guanylate cyclase in rat heart, brain, and kidney (Glover et al. 1995). Isatin has been postulated to function as an endocoid marker of anxiety (Glover and Sandler 1993). It induced an anxiety like response in rodents within a narrow dose range $(15-20 \mathrm{mg} / \mathrm{kg}$ IP). The methods used to investigate the behavioral effect of isatin included the open-field, elevated plus-maze, social interaction, and Vogel's conflict tests (Bhattacharya et al. 1991a; Bhattacharya and Acharya 1993, 1994). This anxiogenic response has been recently confirmed in rhesus monkeys (Palit et al. submitted).

The anxiogenic agent pentylenetetrazole is known to increase rat (Bhattacharya et al. 1991b) and rabbit (Clow et al. 1989) brain isatin levels. Cerebrospinal fluid levels of isatin were found to be elevated in patients with bulimia nervosa (Brewerton et al. 1995).

In the present study we have investigated the possible anxiolytic activity of ICV ANP in rats and the effects of isatin on it.

\section{MATERIAL AND METHODS}

\section{Animals}

Male adult Wistar-strain albino rats (180-200 g) were used. They were group-housed, five per cage $(45 \times 45 \times$ $25 \mathrm{~cm}$ ), unless otherwise mentioned, at an ambient temperature of $25 \pm 1{ }^{\circ} \mathrm{C}$ and $45 \%$ to $55 \%$ relative humidity, with a 12-hour dark/light cycle. The rats had free access to standard pellet chow, unless mentioned otherwise, and drinking water. All experiments were conducted between 0900 and $1400 \mathrm{~h}$. A total of 257 rats were used, of which 163 were intracerebroventricularly cannulated; the rest were not cannulated. The animals were randomly assigned to the different treatment and test groups. Each rat was used only once to ensure that the animals were drug- and test-naive. The number of rats used in each test and treatment group is detailed in the different tables and figures.

Guidelines of the Principles of Laboratory Animal Care manual (NIH 1985) were followed.

\section{Intracerebroventricular Cannulation}

The rats were anesthetized with pentobarbital sodium ( $35 \mathrm{mg} / \mathrm{kg} \mathrm{IP)}$. Anesthesia was assessed by the loss of righting reflex and the absence of pain sensation as indicated by loss of vocalization responses to prick stimulus. A 20-guage 1.5-inch Luer cannula was placed into the right lateral ventricle (using the stereotaxic coordinates AP: + 1.0; L: 1.5, V: 3.0) and fixed to the skull with dental cement (Feldberg and Lotti 1967). The rats were used 1 week later. The correct positioning of the cannula was checked individually by injecting methylene blue after completion of the experiments. Animals with an incorrectly placed cannula were discarded and excluded from the statistical evaluations.

\section{Drugs and Vehicles}

The following drugs were employed: rat natriuretic peptide (ANP; synthetic, purity $99 \%$, peptide content $73 \%$; Sigma, USA), lorazepam (Cipla, India), isatin (SD Fine Chemicals, India), and flumazenil (Hoffman-La Roche, Switzerland). ANP was administered ICV dissolved in $5 \mu \mathrm{l}$ artificial CSF (ACSF; in $\mathrm{mM}: \mathrm{NaCl}, 147$; $\mathrm{KCl}, 2.9 ; \mathrm{MgCl}_{2}, 1.6 ; \mathrm{CaCl}_{2}, 1.7$; and dextrose 2.2, dissolved in triple distilled water). All the other drugs were suspended in $0.9 \%$ saline containing $0.3 \%$ carboxymethyl cellulose and administered IP in a volume of $0.25 \mathrm{ml} / 100 / \mathrm{g}$ body weight. Two sets of control groups were maintained, each receiving equivalent volumes of the ICV or IP administered vehicles. Isatin and flumazenil were used in subanxiogenic doses (Bhattacharya and Acharya 1994) of $10 \mathrm{mg} / \mathrm{kg}$ IP and $5 \mathrm{mg} / \mathrm{kg}$ IP, respectively, and were administered 30 minutes prior to ANP or lorazepam.

\section{Experimental Methods}

The following methods were used to investigate the anxiolytic activity of ANP.

Open-Field Test. The apparatus was a green area of $96 \times 96 \mathrm{~cm}$, divided into 16 squares, placed in a dimly lit (25-W incandescent bulb) room. Naive rats pretreated with the test drugs or their vehicles were placed individually at one corner of the apparatus and observed for the next 15 minutes by a neutral observer unaware of the treatment of the animals, recording the number of squares crossed, period of immobility, rearings and fecal pellets (Bhattacharya et al. 1991a). The pretreatment times for ICV ANP and IP lorazepam, in this and all other procedures employed, were 15 and 30 minutes, respectively. The distribution of animals in each individual test group is given in Table 1.

Elevated Plus-Maze Test. The plus-maze consisted of two opposite arms, $50 \times 10 \mathrm{~cm}$, crossed with two closed 
arms of the same dimensions, with walls $50 \mathrm{~cm}$ high. The arms were connected with a central square, $10 \times 10$ $\mathrm{cm}$, to give the apparatus the shape of a plus sign. The whole apparatus was elevated $50 \mathrm{~cm}$ above the floor and placed in a dimly lit room. Naive rats pretreated with the drugs or their vehicles were placed on the center of the maze, facing an enclosed arm. The number of entries and total time spent on the open and closed arms during the next 5 minutes were recorded by a neutral observer. The results are expressed in terms of percent entries and time spent on the open arms as compared to total entries and time spent on both the open and closed arms (Pellow et al. 1985). The distribution of animals in each test group is given in Tables 2 and 3.

Social Interaction Test. The rats were housed individually for 5 days prior to testing. The social interaction area was a wooden box $(60 \times 60 \times 35 \mathrm{~cm})$ with a solid floor placed in a dimly lit room. On day 6 , the rats were individually subjected to two 7.5-minute familiarization sessions on the test arena at 2-hour intervals. On day 7 , they were paired on the basis of their weights, pretreated with the test drugs or the vehicles, and placed on the test arena for 7.5 minutes. During this period, the time spent by the rats in active social interaction, including sniffing, following, grooming, kicking, boxing, biting, and crawling under or over the partner (Johnston et al. 1988), was scored by a neutral observer. In another experimental group, the rats, treated as before, were placed individually in an 8-beam photocell activity chamber (actophotometer), and the locomotor activity, indicated by photobeam breaks, was recorded during the next 7.5 minutes. The number of animals in each test group is given in Table 4.

Novelty-Suppressed Feeding Test. The test apparatus was the same as that used for the social interaction test and was placed in a dimly lit room. The floor of the wooden box was covered with a $2-\mathrm{cm}$ layer of wooden chips, and 15 laboratory chow pellets were evenly placed on the floor. A similar arrangement was made in the home cages of the rats. Food was removed from the home cage 48 hours prior to testing, but water was provided ad libitum. Following pretreatment with the drugs or their respective vehicles, naive rats were placed individually in the test chamber and the latency to begin eating (defined as chewing of the pellet and not merely sniffing or playing with it), was recorded. If the rats had not eaten within $300 \mathrm{~s}$, the test was terminated and a latency score of $300 \mathrm{~s}$ was assigned. The results were compared with those from another group of rats where latency to feed was recorded in the home cage under identical experimental conditions (Bodnoff et al. 1988). The number of animals in each test group is given in Table 5.
Rotarod Test. Rats were pretreated with the vehicles or the test drugs ( $n=10$ in each group) and placed individually on a rotarod apparatus rotating at a speed of $16 \mathrm{rpm}$. The criterion was the ability of the rat to remain on the rotating rod for $30 \mathrm{~s}$. Each animal was allowed up to three trials to reach criterion, and the percentage of rats not reaching criterion was recorded (Bhattacharya et al. 1995).

\section{Effects of Flumazenil and Isatin on ANP and Lorazepam-Induced Alterations in the Elevated Plus-Maze Test}

Rats were treated with either isatin (10 $\mathrm{mg} / \mathrm{kg}$ IP) or flumazenil ( $5 \mathrm{mg} / \mathrm{kg}$ IP) 30 minutes before ANP or isatin administration and their effects per se and on ANP- and lorazepam-induced changes in the elevated plus-maze test were noted. Saline-treated rats were used as the control group because there was no significant difference between ICV ACSF- and IP salinetreated rats on this test variable. Each test group was comprised of six rats.

\section{Statistical Analysis}

A one-way analysis of variance (ANOVA), followed by the Tukey test, was used for statistical evaluation. A probability value of 0.05 was accepted as statistically significant. The $\chi^{2}$ test was used for statistical analysis of the data in the rotarod test.

\section{RESULTS}

\section{Open-Field Test}

ANP $(100,200$, and $500 \mathrm{ng} /$ rat ICV) produced a doserelated increase in the number of squares crossed and rearing behavior, with concomitant decreases in period of immobility and defecation, the effects induced by the two higher doses of ANP being statistically significant. Lorazepam $(0.5 \mathrm{mg} / \mathrm{kg}$ IP) produced a qualitatively similar response (Table 1).

\section{Elevated Plus-Maze Test}

ANP $(100,200$, and $500 \mathrm{ng} / \mathrm{rat} \mathrm{ICV})$ and lorazepam $(0.5$ $\mathrm{mg} / \mathrm{kg} \mathrm{IP}$ ) did not significantly alter the total arm entries on the elevated plus-maze (Table 2). ANP (100, 200, and $500 \mathrm{ng} / \mathrm{rat} \mathrm{ICV}$ ) induced a dose-related increase in number of entries and time spent on the open arms compared with the ACSF-treated control group. The effect of the lowest dose of ANP used was not significant. Lorazepam (0.5 mg/kg IP) produced a qualitatively similar response (Table 3 ). The total number of entries and total time spent in seconds on the open and closed 
Table 1. Effects of ICV ANP and IP Lorazepam on Open-Field Parameters in Rats

\begin{tabular}{|c|c|c|c|c|c|}
\hline Groups & $n$ & $\begin{array}{c}\text { Square Crossed } \\
(\mathrm{N})\end{array}$ & $\begin{array}{c}\text { Immobility } \\
\text { (s) }\end{array}$ & $\begin{array}{l}\text { Rearing } \\
\text { (N) }\end{array}$ & $\begin{array}{c}\text { Fecal Pellets } \\
(\mathrm{N})\end{array}$ \\
\hline $\begin{array}{l}\text { Control I } \\
\text { (ACSF) }\end{array}$ & 16 & $122.6 \pm 12.4$ & $32.9 \pm 5.2$ & $22.9 \pm 3.3$ & $5.9 \pm 0.8$ \\
\hline ANP & & & & & \\
\hline $\begin{array}{l}100 \mathrm{ng} / \mathrm{rat} \\
200 \mathrm{ng} / \mathrm{rat} \\
500 \mathrm{ng} / \mathrm{rat}\end{array}$ & $\begin{array}{l}6 \\
6 \\
6\end{array}$ & $\begin{array}{l}148.2 \pm 11.4 \\
167.2 \pm 13.6^{a} \\
182.9 \pm 9.6^{a}\end{array}$ & $\begin{array}{l}24.9 \pm 3.6 \\
19.4 \pm 3.8^{a} \\
16.2 \pm 2.9^{i}\end{array}$ & $\begin{array}{l}32.5 \pm 5.6 \\
39.2 \pm 3.9^{n} \\
512+26^{a}\end{array}$ & $\begin{array}{l}4.6 \pm 0.9 \\
3.2 \pm 0.9^{a} \\
20 \pm 06^{a}\end{array}$ \\
\hline $\begin{array}{r}\text { Control II } \\
\text { (Saline) }\end{array}$ & 10 & $132.0 \pm 10.6$ & $28.6 \pm 3.7$ & $20.2 \pm 2.9$ & $5.0 \pm 0.9$ \\
\hline $\begin{array}{l}\text { Lorazepam } \\
\qquad(0.5 \mathrm{mg} / \mathrm{kg})\end{array}$ & 6 & $178.0 \pm 8.4^{i 7}$ & $16.6 \pm 1.9^{a}$ & $56.6 \pm 3.8^{n}$ & $2.2 \pm 0.6^{a}$ \\
\hline
\end{tabular}

arms (means \pm SEM) in the ACSF-treated control group were $6.8 \pm 0.6$ and $14.2 \pm 0.9$, and $38.4 \pm 6.2$ and $192.2 \pm$ 13.6 , respectively. Reciprocal values in the saline-treated control group were $7.9 \pm 0.9$ and $13.6 \pm 0.8$, and $40.4 \pm$ 7.6 and $182.7 \pm 19.3$, respectively.

\section{Social Interaction Test}

ANP (200 and $500 \mathrm{ng} / \mathrm{rat}$ ICV) and lorazepam (0.5 mg/ $\mathrm{kg}$ IP) increased the total time spent by the paired rats in social interaction without significantly affecting locomotor activity. However, the effect of ANP (100 ng/rat) was not significant in this test (Table 4).

\section{Novelty-Suppressed Feeding Test}

ANP (200 and $500 \mathrm{ng} / \mathrm{rat} \mathrm{ICV}$ ) and lorazepam $(0.5 \mathrm{mg} /$ $\mathrm{kg}$ IP) significantly reduced the latency to feed in an unfamiliar environment, compared with the feeding latency of vehicle-treated rats. The effect of ANP (100 ng/rat) was not significant. Neither drug significantly altered the latency in rats kept in the familiar environment of the home cage (Table 5).

\section{Rotarod Test}

ANP (100, 200, and $500 \mathrm{ng} / \mathrm{rat} \mathrm{ICV})$ and lorazepam $(0.5$ $\mathrm{mg} / \mathrm{kg}$ IP) had marginal and non-significant ( $\chi^{2}$ test) effects on this test. The performance deficit ( $n=10$ in each group) with $\operatorname{ANP}(100,200$, and $500 \mathrm{ng} /$ rat $)$ and lorazepam was $0 \%, 20 \%, 10 \%$, and $20 \%$, respectively.

\section{Effects of Isatin and Flumazenil on Anxiolytic Actions of ANP and Lorazepam}

The significant increase in the number of entries and time spent on the open arms of the elevated plus-maze induced by ANP (200 and $500 \mathrm{mg} / \mathrm{rat} \mathrm{ICV}$ ) and lorazepam $(0.5 \mathrm{mg} / \mathrm{kg}$ IP) was interpreted as an index of their anti-anxiety activity. Both isatin $(10 \mathrm{mg} / \mathrm{kg} \mathrm{IP})$ and flumazenil $(5 \mathrm{mg} / \mathrm{kg}$ IP) reduced the time spent and number of entries on the open arms, though the effects were not significant. Isatin significantly reduced the anxiolytic action of ANP (200 and $500 \mathrm{ng} / \mathrm{rat} \mathrm{ICV)}$ without affecting the action of lorazepam $(0.5 \mathrm{mg} / \mathrm{kg}$ IP). Flumazenil markedly attenuated the anxiolytic effect of lorazepam without significantly affecting the action of either dose of ANP (Figure 1).

\section{DISCUSSION}

The present investigation indicates that ICV-administered ANP induces anxiolytic activity in rats, an effect comparable with that of the benzodiazepine (BDZ)

Table 2. Effects of ICV ANP and Lorazepam on total number of entries on both open and closed arms of the elevated plus-maze in rats

\begin{tabular}{lcc}
\hline Groups & $n$ & $\begin{array}{c}\text { Total } \\
\text { Number } \\
\text { of Entries }\end{array}$ \\
\hline $\begin{array}{l}\text { Control I } \\
\text { (ACSF) }\end{array}$ & 16 & $21.0 \pm 0.8$ \\
ANP & & \\
$100 \mathrm{ng} / \mathrm{rat}$ & 5 & $19.6 \pm 1.2$ \\
$200 \mathrm{ng} / \mathrm{rat}$ & 6 & $18.4 \pm 1.4$ \\
$500 \mathrm{ng} / \mathrm{rat}$ & 6 & $18.0 \pm 1.6$ \\
$\begin{array}{c}\text { Control II } \\
\text { (Saline) }\end{array}$ & 8 & $21.5 \pm 0.9$ \\
Lorazepam & & \\
$(0.5 \mathrm{mg} / \mathrm{kg})$ & 6 & $19.2 \pm 1.6$ \\
\hline
\end{tabular}

None of the drug-treated values were statistically significant in comparison to the respective control data (Tukey test). 
Table 3. Effects of ICV ANP and Lorazepam in the Elevated Plus-Maze Test in Rats

\begin{tabular}{|c|c|c|c|c|c|}
\hline Groups & $n$ & $\begin{array}{l}\text { Time Spent on } \\
\text { Open Arms (\%) }\end{array}$ & $\begin{array}{c}\text { Increase } \\
(\%)\end{array}$ & $\begin{array}{c}\text { Entries on } \\
\text { Open Arms (\%) }\end{array}$ & $\begin{array}{c}\text { Increase } \\
(\%)\end{array}$ \\
\hline $\begin{array}{l}\text { Control I } \\
\text { (ACSF) }\end{array}$ & 16 & $23.8 \pm 4.8$ & - & $34.6 \pm 5.0$ & - \\
\hline $\begin{array}{l}\text { ANP } \\
100 \mathrm{ng} / \mathrm{rat} \\
200 \mathrm{ng} / \mathrm{rat} \\
500 \mathrm{ng} / \mathrm{rat}\end{array}$ & $\begin{array}{l}5 \\
6 \\
6\end{array}$ & $\begin{array}{l}34.9 \pm 5.2 \\
44.4 \pm 3.8^{n} \\
52.8 \pm 3.2^{n}\end{array}$ & $\begin{array}{r}46.6 \\
86.5 \\
122.0\end{array}$ & $\begin{array}{l}43.9 \pm 4.6 \\
52.9 \pm 3.6^{a} \\
65.6 \pm 2.9^{a}\end{array}$ & $\begin{array}{l}26.9 \\
52.9 \\
89.6\end{array}$ \\
\hline $\begin{array}{r}\text { Control II } \\
\text { (Saline) }\end{array}$ & 8 & $28.6 \pm 3.9$ & - & $36.8 \pm 4.3$ & - \\
\hline $\begin{array}{l}\text { Lorazepam } \\
\qquad(0.5 \mathrm{mg} / \mathrm{kg})\end{array}$ & 6 & $59.9 \pm 2.6^{i}$ & 109.4 & $68.4 \pm 2.6^{n}$ & 85.9 \\
\hline
\end{tabular}

aStatistical significance at $p<.05$, compared with the respective vehicle-treated control groups (Tukey test). Results are means \pm SEM.

lorazepam, as assessed by their effects on a number of paradigms subjected to thorough critical appraisal and validated as animal models of clinical anxiety (Bodnoff et al. 1988; Lister 1990). Thus, both drugs increased ambulation and rearing while decreasing immobility and defecation in the open-field test. They also augmented the duration of stay and number of entries on the open arms of the elevated plus-maze, as well as the duration of social interaction in paired rats. Both drugs decreased the feeding latency of 48-hour food-deprived rats in a novel environment without affecting feeding latency in the home cage. All these models are based on the assumption that when naive rats are placed in an unfamiliar environment, they experience emotional conflict, which is reflected by a diminution in normal behavior patterns (Lister 1990). These behavioral perturbations are accentuated by anxiogenic agents and attenuated by anxiolytics under identical experimental conditions (Bodnoff et al. 1988; Lister 1990). An essential prerequisite is that the proposed anxiolytic agent should not induce significant motor deficit in the doses used (Griebel et al. 1993), a condition maintained in this study, as indicated by the absence of any significant alteration in locomotor activity induced by either ANP or lorazepam and the absence of motor deficit in the rotarod test.

An earlier investigation (Heilig et al. 1992) has indicated that ANP does not exhibit significant anxiolytic-like activity when tested in an operant conflict paradigm, the Geller-Seifter test. The reason for this discrepancy is not apparent. However, buspirone and related anxiolytic agents have been reported to have insignificant effects on the traditional conflict-type animal models of anxiety, including the Geller-Seifter and Vogel-type procedures in rats (Barrett and Vanover 1993). The conflict procedures used in the evaluation and development of benzodiazepines were considered problematic even before the introduction of buspirone because they used electric shock, food or water deprivation, and learned behavior (Chopin and Briley 1987). These concerns re-

Table 4. Effects of ICV ANP and IP Lorazepam in the Social Interaction Test in Paired Rats and on Locomotor Activity

\begin{tabular}{|c|c|c|c|c|c|}
\hline Groups & $\begin{array}{c}n \\
\text { (pairs) }\end{array}$ & $\begin{array}{c}\text { Time Spent in } \\
\text { Social Interaction } \\
(\%)\end{array}$ & $\begin{array}{c}\text { Increase } \\
(\%)\end{array}$ & $n$ & $\begin{array}{c}\text { Locomotor } \\
\text { Activity (counts) }\end{array}$ \\
\hline $\begin{array}{l}\text { Control I } \\
\text { (ACSF) }\end{array}$ & 10 & $31.9 \pm 4.6$ & - & 20 & $142.6 \pm 26.4$ \\
\hline $\begin{array}{l}\text { ANP } \\
100 \mathrm{ng} / \mathrm{rat} \\
200 \mathrm{ng} / \mathrm{rat} \\
500 \mathrm{ng} / \mathrm{rat}\end{array}$ & $\begin{array}{l}5 \\
6 \\
6\end{array}$ & $\begin{array}{l}39.6 \pm 3.9 \\
49.2 \pm 3.8^{a} \\
64.3 \pm 2.8^{a}\end{array}$ & $\begin{array}{r}24.1 \\
54.2 \\
101.6\end{array}$ & $\begin{array}{l}10 \\
12 \\
12\end{array}$ & $\begin{array}{l}139.4 \pm 16.9 \\
136.4 \pm 19.7 \\
126.8 \pm 22.4\end{array}$ \\
\hline $\begin{array}{r}\text { Control II } \\
\text { (Saline) }\end{array}$ & 6 & $36.2 \pm 3.9$ & & 12 & $116.6 \pm 28.2$ \\
\hline $\begin{array}{l}\text { Lorazepam } \\
\qquad(0.5 \mathrm{mg} / \mathrm{kg})\end{array}$ & 6 & $68.4 \pm 4.3^{n}$ & 88.9 & 12 & $122.9 \pm 19.6$ \\
\hline
\end{tabular}

"Statistical significance at $p<.05$ compared with the respective vehicle-treated control groups (Tukey test). Results are means \pm SEM. 
Table 5. Effects of ICV ANP and IP Lorazepam on Feeding Latency of 48-Hour Food-Deprived Rats in Unfamiliar and Familiar Environments

\begin{tabular}{|c|c|c|c|c|c|}
\hline Groups & $n$ & $\begin{array}{l}\text { Latency to } \\
\text { feed in home } \\
\text { cage(s) }\end{array}$ & $\begin{array}{c}\text { Percent } \\
\text { decrease }\end{array}$ & $\begin{array}{l}\text { Latency to } \\
\text { feed in test } \\
\text { chamber(s) }\end{array}$ & $\begin{array}{c}\text { Percent } \\
\text { decrease }\end{array}$ \\
\hline $\begin{array}{l}\text { Control I } \\
\text { (ACSF) }\end{array}$ & 8 & $59.6 \pm 6.8$ & - & $169.2 \pm 19.6$ & - \\
\hline $\begin{array}{l}\text { ANP } \\
100 \mathrm{ng} / \mathrm{rat} \\
200 \mathrm{ng} / \mathrm{rat} \\
500 \mathrm{ng} / \mathrm{rat}\end{array}$ & $\begin{array}{l}5 \\
6 \\
6\end{array}$ & $\begin{array}{l}50.4 \pm 6.8 \\
48.2 \pm 4.6 \\
44.6 \pm 5.8\end{array}$ & $\begin{array}{l}15.4 \\
19.1 \\
25.2\end{array}$ & $\begin{array}{r}126.2 \pm 21.9 \\
92.6 \pm 7.8^{a} \\
61.6 \pm 4.0^{a}\end{array}$ & $\begin{array}{l}29.8 \\
45.3 \\
63.6\end{array}$ \\
\hline $\begin{array}{r}\text { Control II } \\
\text { (Saline) }\end{array}$ & 8 & $54.2 \pm 5.9$ & - & $178.4 \pm 16.3$ & - \\
\hline $\begin{array}{l}\text { Lorazepam } \\
\qquad(0.5 \mathrm{mg} / \mathrm{kg})\end{array}$ & 6 & $44.2 \pm 3.9$ & 19.5 & $84.2 \pm 8.2^{a}$ & 52.8 \\
\hline
\end{tabular}

"Statistical significance at $p<.05$ compared with the respective vehicle-treated control groups (Tukey test). Results are means \pm SEM.

volved around the potential limitations or complications of using electric shock to suppress responding, a behavior which is not as "natural" as the response to aversive situations. Benzodiazepines increase food and water consumption, which could vitiate results depending on anxiolytic-like activity based on increased food or water intake (Barrett and Vanover 1993). Operant behavior is considered less useful than unconditional procedures (used in the present investigation) because the latter take more species-relevant behaviors into consideration, do not involve a learned component, and retain predictive validity (Lister 1990).

Practically all the experimental methods previously used to establish the involvement of ANP in learning processes have been based on fear-motivated attenuation of memory functions (Bidzseranova et al. 1993), and the effective doses of ANP were similar to those found to induce anxiolysis in this study. It is, therefore,

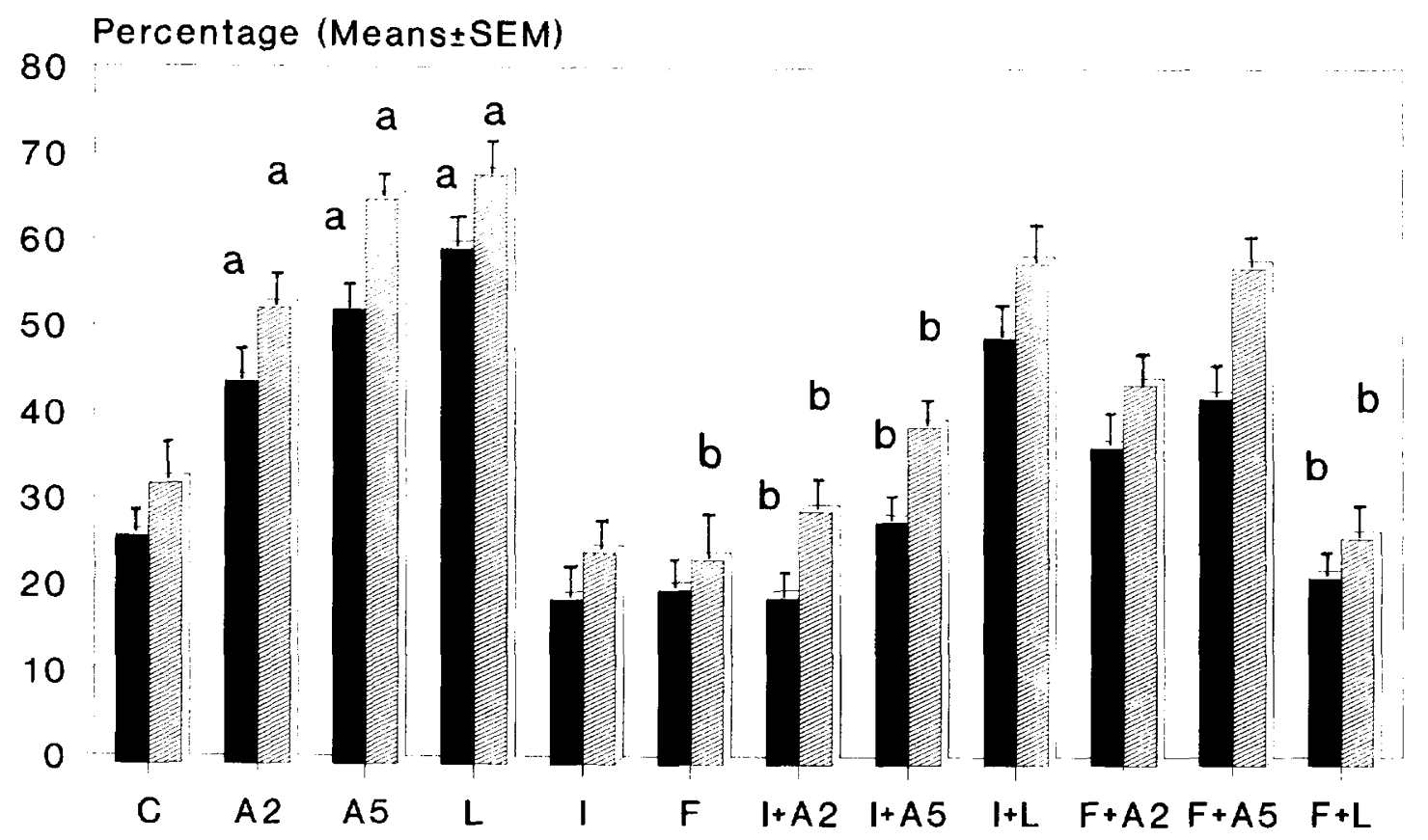

Figure 1. Effects of isatin and flumazenil on ICV ANP and IP lorazepam actions on the elevated plus-maze test in rats. Results are means \pm SEM. ", Statistical significance at $\mathrm{p}<.05$ compared with the respective vehicle-treated control groups; $b$, statistical significance at $p<.05$ compared with the respective ANP or lorazepam-treated control group; $C$, control; $A 2$, ANP (200 ng/rat); A5, ANP (500 ng/rat); L, lorazepam (0.5 mg/kg); I, isatin; F, flumazenil; OA, open arms of the maze; solid bars, time spent on OA $(\%)$; gray bars, OA entries $(\%) . n=$ six animals in each group. 
possible that at least part of the reported facilitative effect of ANP on learning and memory is caused by its anxiety-attenuating effect.

As expected, flumazenil, a selective $\mathrm{BDZ}$ receptor antagonist (Nutt 1988) attenuated the anxiolytic effect of lorazepam, as assessed by the elevated plus-maze test. The anxiolytic effect of ANP was, however, unchanged. Conversely, isatin failed to alter the anxiolytic effect of lorazepam but significantly diminished the anxiolytic effect of ANP, which is consonant with the observation that isatin may be an antagonist at ANP receptors and has minimal affinity for BDZ receptors (Glover et al. 1988). The finding that ANP-induced anxiolysis is not mediated via BDZ receptors may explain why unlike the BDZs, it induces an antiamnesic effect and not amnesia (Ghoneim and Mewaldt 1990).

It has been shown that centrally administered ANP preferentially decreases dopamine (DA) concentrations in the septum and hypothalamus of the rat, where endogenous ANP levels are highest and ANP receptors predominate (Nakao et al. 1986). On the contrary, isatin, in anxiogenic doses facilitates rat brain dopaminergic activity (Bhattacharya and Acharya 1993). It was proposed that this effect of isatin was due to stimulation of 5-hydroxytryptamine-3 $\left(5-\mathrm{HT}_{3}\right)$ receptors (Bhattacharya and Acharya 1994), which function as heteroreceptors modulating mesolimbic DA activity (Costall et al. 1990; Wang et al. 1992). 5- $\mathrm{HT}_{3}$ receptor antagonists were found to inhibit the anxiogenic action of isatin and its augmentation of rat brain DA levels (Bhattacharya and Acharya 1994). There is evidence that $5-\mathrm{HT}_{3}$ receptors are involved in the modulation of anxiety, with anxiogenic agents stimulating and anxiolytic agents, including ondansetron, functioning as antagonists at these receptor sites (Costall et al. 1990; Bhattacharya and Acharya 1994). This modulation may be induced by an increase or decrease of mesolimbic dopaminergic activity by $5-\mathrm{HT}_{3}$ receptor agonists and antagonists, respectively. It has been shown that the modulatory effect of 5 -HT on dopaminergic activity is primarily mediated through 5- $\mathrm{HT}_{3}$ receptors (Wang et al. 1992; Raiteri et al. 1993). The octapeptide cholecystokinin (CCK), widely distributed in the mammalian central system, has been postulated to function as an endogenous anxiogenic peptide based on extensive preclinical and clinical evidence (Harro and Vasar 19991; Lydiard 1994). Like isatin, the anxiogenic action of CCK in rats has been shown to be, at least partly, mediated through a $5-\mathrm{HT}_{3}$ receptor-DA nexus (Raiteri et al. 1993).

The 41-amino acid neuropeptide corticotropinreleasing factor (CRF) appears to play a pivotal role in stress and anxiety (Nemeroff 1992). ANP has been shown to inhibit CRF-mediated adrenocorticotrophic hormone (ACTH) release (Fink et al. 1991) and to lower plasma cortisol levels (Weidman et al. 1989). On the contrary, vasopressin, which induces physiological ef- fects contrary to those of ANP, produces anxiogenic effects (Swedo et al. 1992) and promotes the release of ACTH (Sklar and Schrier 1983). Interestingly, vasopressin promotes the release of neuronal DA (Sklar and Schrier 1983), and intraventricular administration of DA is associated with an antidiuretic effect (Bridges et al. 1976). Isatin has been shown to have an antidiuretic effect in rats (Hota and Acharya 1994) and to inhibit the diuretic and natriuretic effects of centrally administered ANP (unpublished data).

The present study demonstrates the anxiolytic action of ANP in a range of animal models and its antagonism by isatin, but not by flumazenil, and adds additional evidence to a theory of anxiomodulation by a non-BDZ system and a likely interaction between control of anxiety and natriuresis.

\section{REFERENCES}

Anand-Srivastava MB, Trachte GJ (1993): Atrial natriuretic factor receptors and signal transduction mechanisms. Pharmacol Rev 45:457-497

Barrett JE, Vanover KE (1993): 5-HT receptors as targets for the development of novel anxiolytic drugs: Models, mechanisms and future directions. Psychopharmacology 112:1-12

Bhattacharya SK, Acharya SB (1993): Further investigations on the anxiogenic activity of isatin. Biogenic Amines $9: 453-463$

Bhattacharya SK, Acharya SB (1994): Anxiogenic agents and $5-\mathrm{HT}_{3}$ receptors. In Dhawan BN, Srimal RC, Raghubir R, Rapaka RS (eds), Recent Advances in the Study of Neurotransmitter Receptors. Lucknow, Central Drug Research Institute, pp 77-80

Bhattacharya SK, Mitra SK, Acharya SB (1991a): Anxiogenic action of isatin, a putative biological factor, in rodents. J Psychopharmacol 5:202-206

Bhattacharya SK, Clow A, Przyborowska A, Halket J, Glover V, Sandler M (1991b): Effect of aromatic aminoacids, pentylenetetrazole and yohimbine on isatin and tribulin activity in rat brain. Neurosci Lett 132:44-46

Bhattacharya SK, Mohan Rao PJR, Sen AP (1995): Anxiogenic activity of intraventricularly administered bradykinin in rats. J Psychopharmacol 9:348-354

Bidzseranova A, Gueron J, Toth G, Varga J, Telegdy G (1992): Structure-activity studies on the effects of atrial natriuretic peptide, brain natriuretic peptide and their ana$\operatorname{logs}$ on fear-motivated learning behavior in rats. Neuropeptides 23:61-65

Bidzseranova A, Varga J, Telegdy G (1993): The effects of brain natriuretic peptide on electroconvulsive shockinduced amnesia in rats. The role of neurotransmitters. Eur J Pharmacol 232:305-306

Bodnoff SR, Suranyi-Cadotte B, Aitken DH, Quirion R, Mesney MJ (1988): The effects of chronic antidepressant treatment on an animal model of anxiety. Psychopharmacology 95:298-302 
Brewerton TD, Zealberg JJ, Lydiard RB, Glover V, Sandler M, Ballenger JC (1995): CSF isatin is elevated in bulimia nervosa. Biol Psychiatry 37:481-483

Bridges TE, Hillhause EW, Jones MT (1976): The effect of dopamine on neurohypophysial hormone release in vivo and from the rat neural lobe and hypothalamus in vitro. J Physiol Lond 260:647-666

Chopin P, Briley M (1987): Animal models of anxiety: The effect of compounds that modify 5-HT transmission. Trends Pharm Sci 8:383-388

Clow A, Davidson J, Glover V, Halket J, Milton AS, Sandler M, Watkins PJ (1989): Isatin and tribulin concentrations are increased in rabbit brain but not liver following pentylenetetrazole administration. Neurosci Lett 107:327-330

Costall B, Naylor RJ, Tyers MB (1990): The psychopharmacology of 5- $\mathrm{HT}_{3}$ receptors. Pharmacol Ther 47:181-202

de Bold AJ, Berenstein HB, Veress AT, Sonnenberg H (1981): $A$ rapid and potent natriuretic response to intravenous injection of atrial myocardial extracts in rats. Life Sci 28:89-94

Feldberg W, Lotti VJ (1967): Temperature responses to monoamines and an inhibitor of $\mathrm{MAO}$ injected into the cerebral ventricles of rats. $\mathrm{Br} \mathrm{J}$ Pharmacol Chemother 31:152-161

Fink G, Dow RC, Casley D, Johnston CI, Lim AT, Coplolov DL, Bennie J, Carroll S, Dick H (1991): Atrial natriuretic peptide is a physiological inhibitor of ACTH release: Evidence from immunoneutralization in vivo. J Endocrinol 131:R9-12

Ghoneim MM, Mewaldt SP (1990): Benzodiazepines and human memory: A review. Anesthesiology 72:926-938

Glover V, Medvedev A, Sandler M (1995): Isatin is a potentendogenous antagonist of guanylate cyclase-coupled atrial natriuretic peptide receptors. Life Sciences 57: 2073-2079

Glover V, Sandler M (1993): Tribulin and isatin: An update. In Yasuhara $\mathrm{H}$, Parvez SM, Oguchi K, Sandler $\mathrm{M}$, Nagatsu $T$ (eds), Monoamine oxidase: Basic and Clinical Aspects. Utrecht, VSP, pp 61-71

Glover, V, Halket JM, Watkins PJ, Clow A, Goodwin BL, Sandler M (1988): Isatin: Identity with the purified endogenous monoamine oxidase inhibitor tribulin. J Neurochem 51:656-659

Griebel G, Moreau J, Jenck F, Martin JR, Misslin R (1993): Some critical determinants of the behavior of rats in the elevated plus-maze. Behav Proc 29:37-48

Harro J, Vasar E (1991): Cholecystokinin-induced anxiety: How is it reflected in studies on exploratory behavior? Neurosci Biobehav Rev 15:473-477

Heilig M, McLeod S, Koob GK, Britton KT (1992): Anxiolytic like effect of neuropeptide Y (NPY), but not other peptides in an operant conflict test. Regul Peptides 41:61-69

Hota D, Acharya SB (1994): Studies on peripheral actions of isatin. Indian J Exp Biol 32:710-717

Johnston AL, Baldwin HE, File SE (1988): Measures of anxiety and stress in the rat following chronic treatment with yohimbine. J Psychopharmacol 2:33-38

Kawata M, Nakao K, Morii N, Kiso Y, Yamashita H, Imura H, Sano Y (1985): Atrial natriuretic polypeptide: Topographical distribution in the rat brain by radioimmu- noassay and immunohistochemistry. Neuroscience 16: 521-546

Lang CC, Choy AJ, Struthers AD (1992): Atrial and brain natriuretic peptides: A dual natriuretic peptide system potentially involved in circulatory homeostasis. Clin Sci 83:519-527

Lister RG (1990): Ethologically based animal models of anxiety disorders. Pharmacol Ther 46:321-340

Lydiard RB (1994): Neuropeptides and anxiety: Focus on cholecystokinin. Clin Chem 40:315-318

Morii N, Nakao K, Sugawara A, Sakamoto M, Suda M, Shimokura M, Kiso Y, Yamori Y, Imura H (1985): Occurrence of atrial natriuretic polypeptide in brain. Biochem Biophys Res Commun 127:413-418

Nakao K, Katsuura G, Morii N, Itoh H, Shiono S, Yamada T, Sugawara A, Sakamoto M, Saito Y, Eigyo M, Matsushita A, Imura H (1986): Inhibitory effect of centrally administered atrial natriuretic polypeptide on the brain dopaminergic system in rats. Eur J Pharmacol 131:171177

National Institutes of Health (1985): Principles of Laboratory Animal Care. NIH Publication 85-23. Bethesda, MD, National Institutes of Health

Nemeroff CB (1992): New vistas in neuropeptide research in neuropsychiatry: Focus on corticotropin-releasing factor. Neuropsychopharmacol 6:69-75

Nicholls MG (1994): Minisymposium: The natriuretic peptide hormones. Editorial and historical review. J Int Med 235:507-514

Nutt DJ (1988): Benzodiazepine receptor ligands. Neurotransmissions $4: 2 \mathrm{P}$ (abstr.)

Palit G, Patnaik GK, Bhattacharya SK (submitted): Anxietylike action of isatin, a putative biological factor in rhesus monkeys. Behavioral Pharmacology

Pellow S, Chopin P, File SE, Briley M (1985): Validation of open: Closed arm entries in the elevated plus-maze as a measure of anxiety in the rat. J Neurosci Meth 14:149-167

Raiteri M, Paudice P, Vallebuona F (1993): Release of cholecystokinin in the central nervous system. Neurochem Int 22:519-527

Sandler M, Przyborowska A, Halket JM, Watkins P, Glover V, Coates ME (1991): Urinary but not brain isatin levels are reduced in germ-free rats. J Neurochem 57:1074-1075

Sklar AH, Schrier RW (1983): Central nervous system mediators of vasopressin release. Physiol Rev 63:1243-1280

Swedo SE, Leonard HL, Kruesi MJ, Rettew DC, Listwak SJ, Berrettini W, Stipetic M, Hamburger S, Gold PW, Potter WZ (1992): Cerebrospinal fluid neurochemistry in children and adolescents with obsessive-compulsive disorder. Arch Gen Psychiatry 49:29-36

Wang RY, Ashby CR, Zhang JY (1992): Functional roles of 5 - $\mathrm{HT}_{3}$-like receptors in the medial prefrontal cortex. Adv Biosci 85:81-96

Weidman P, Saxenhofer H, Shaw SG, Ferrier C (1989): Atrial natriuretic peptide in man. J Steroid Biochem 3:229-241

Wigle DA, Bennett BM, Jennings DB, Sarda IR, Flynn TG, Pang SC (1992): Biological effects of rat iso-atrial natriuretic polypeptide and brain natriuretic peptide are indistinguishable from each other. Canad J Physiol Pharmacol 70:1525-1528 